\title{
Synthesis of Lipids from Acetate Is Not Characteristic of Acholeplasma or Ureaplasma Species
}

\author{
J. D. POLLACK, ${ }^{1 *}$ K. D. BEAMAN, ${ }^{1 \dagger}$ AND J. A. ROBERTSON ${ }^{2}$ \\ Department of Medical Microbiology and Immunology, The Ohio State University, Columbus, Ohio $43210,{ }^{1}$ and \\ Department of Medical Microbiology, University of Alberta, Edmonton, Canada T6G $2 H 7^{2}$
}

Previous studies of Acholeplasma species indicated that this genus could be separated from Mycoplasma on the basis of the ability to synthesize lipids from acetate. We report that recently described strains of Acholeplasma florum (strain L1 isolated from a lemon flower and strain GF-1 isolated from a grapefruit flower) and two unclassified Acholeplasma strains (strain J233 from coconut palm and Acholeplasma sp. strain PS-1 from an insect) convert little if any acetate carbon to lipid, in contrast to Acholeplasma sp. strain 0502-CL1 isolated from broccoli and six other established Acholeplasma species of animal origin. Thus, the ability to synthesize lipid from acetate in Edward test medium containing horse serum is not characteristic of all members of the genus Acholeplasma (class Mollicutes), but appears to be a property only of a subgroup in the genus containing the species that are most frequently isolated from animals (Acholeplasma laidlawii, Acholeplasma granularum BTS39, Acholeplasma oculi 19L, Acholeplasma equifetale N93, and probably Acholeplasma axanthum S743 and Acholeplasma modicum PG49). Like other Mycoplasma species which we studied, Mycoplasma bovigenitalium PG11, Mycoplasma hominis PG27, Mycoplasma arginini $\mathrm{G} 230$, and four sterol-requiring mycoplasmas of insect or plant origin (Mycoplasma sp. strain MQ3 from an insect, Mycoplasma sp. strain pommier from an apple, Mycoplasma sp. strain melaleuca from a Melaleuca flower, and Mycoplasma sp. strain 831-C4 from lettuce) convert little acetate to lipid. Similarly, eight serovars of Ureaplasma urealyticum convert little if any acetate to lipid.

The Mycoplasmatales, the only order in the class Mollicutes, contains three families, the Mycoplasmataceae, with two genera (Mycoplasma and Ureaplasma), and the Acholeplasmataceae and Spiroplasmataceae, each containing one genus (Acholeplasma and Spiroplasma, respectively) (3). These three families are distinguished by whether sterol is essential for growth, by their genome sizes, by the ability to hydrolyze urea, by the localization of reduced nicotinamide adenine dinucleotide oxidase activity, and by the presence of helical forms during some phase of growth (3). We have suggested that members of the genus Acholeplasma, the single genus in the Acholeplasmataceae, can be distinguished from Mycoplasma species by their ability to synthesize lipid from acetate $(4,6)$. Other workers have reported that a strain of Ureaplasma urealyticum also synthesizes lipid from acetate (10) and that Spiroplasma citri does not (2).

We examined a number of sterol-requiring and non-sterolrequiring plant and insect isolates, as well as ureaplasmas and other members of the Mollicutes, for their ability to synthesize lipids from acetate. Contrary to our expectation, lemon flower strain $\mathrm{L} 1$ and grapefruit flower strain GF-1 of Acholeplasma florum, two other Acholeplasma sp. strains, and eight serovars of $U$. urealyticum did not synthesize significant amounts of lipid from acetate.

\section{MATERIALS AND METHODS}

Organisms. Mycoplasma bovigenitalium PG11, Mycoplasma sp. strain MQ3 (insect), Mycoplasma sp. strain pommier (apple), Mycoplasma sp. strain melaleuca (flower), Acholeplasma laidlawii $\mathrm{H} 3-10$, A. laidlawii $643 \mathrm{~N}$, Acholeplasma morum S2, Acholeplasma hippikon $\mathrm{C} 1$, A. florum L1 (lemon flower) passage 3, A. florum GL-1 (grapefruit flower) pas-

\footnotetext{
* Corresponding author.

† Present address: Department of Pathology, Yale University, New Haven, CT 06510.
}

sage 5, Acholeplasma sp. strain 0502-CL1 (broccoli) passage 12, Acholeplasma sp. strain J233 (coconut palm) passage 10, and Acholeplasma sp. strain PS-1 (insect) passage 1 were obtained from J. G. Tully, National Institutes of Health, Frederick, Md. Mycoplasma sp. strain 831-C4 (lettuce) was isolated by and obtained from N. L. Somerson, Ohio State University, Columbus. A. laidlawii B-PG9, Mycoplasma hominis PG27, Mycoplasma gallisepticum S6, Mycoplasma pulmonis ATCC 19612, Mycoplasma arginini G230, and serovar standard strains of Ureaplasma urealyticum (9) were obtained from our stock collections.

Media and growth conditions. All Acholeplasma and $M y$ coplasma species were grown in our modification of Edward medium (1). The media were supplemented with $2 \%(\mathrm{vol} / \mathrm{vol})$ (acholeplasmas) or $4 \%$ ( $\mathrm{vol} / \mathrm{vol})$ (mycoplasmas) heat-inactivated $\left(56^{\circ} \mathrm{C}, 1 \mathrm{~h}\right)$ horse serum (control lots 268095 and 200011 H; K. C. Biologicals, Lenexa, Kans.). Media for the growth of $M$. arginini were supplemented with L-arginine hydrochloride (Calbiochem, La Jolla, Calif.) at a final concentration of $0.1 \%(\mathrm{wt} / \mathrm{vol})$. Ureaplasmas were grown in Bbroth as described by Robertson (8). All growth media contained approximately $5 \times 10^{5} \mathrm{dpm}$ of $\left[U_{-}{ }^{14} \mathrm{C}\right]$ acetic acid (sodium salt; 52 to $58 \mathrm{mCi} / \mathrm{mmol}$; ICN, Irvine, Calif., or Amersham Corp., Arlington Heights, Ill.) per ml. Temperature-equilibrated media $(125$ to $250 \mathrm{ml})$ were inoculated with 1 to 3-day-old cultures of acholeplasmas or mycoplasmas ( 2 to $10 \%, \mathrm{vol} / \mathrm{vol})$ or ureaplasmas $(0.01 \%, \mathrm{vol} / \mathrm{vol})$ grown under the same conditions. Most organisms were incubated at $37^{\circ} \mathrm{C}$; the exceptions were Mycoplasma sp. strain $\mathrm{MQ} 3$, Mycoplasma sp. strain melaleuca, and Acholeplasma sp. strain PS-1, which were incubated at $30^{\circ} \mathrm{C}$. After 1 to 3 days of incubation, the cells were harvested, and in most instances the pellets were washed four times in 200 volumes of Kappa buffer by centrifugation at $16,000 \times g$ for $20 \mathrm{~min}$ at $4^{\circ} \mathrm{C}$ (7). Ureaplasma pellets were washed four times in 300 volumes of Kappa buffer by centrifugation at $29,000 \times g$ for $20 \mathrm{~min}$ at $4^{\circ} \mathrm{C}$. 


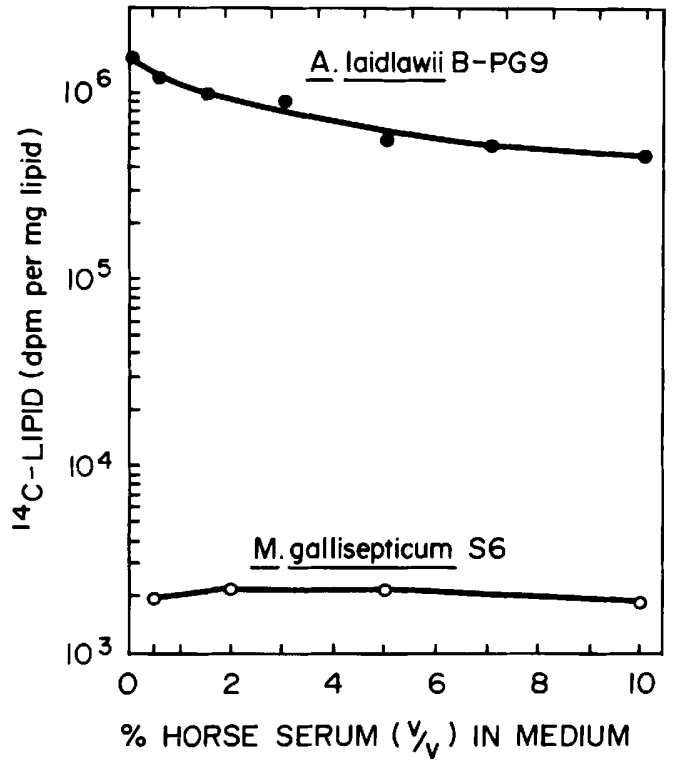

FIG. 1. Effect of different amounts of horse serum in Edward medium (1) on the incorporation of radioactivity from $\left[U_{-}{ }^{14} \mathrm{C}\right]$ acetate into the lipids of two growing Mollicutes strains.

The cells of Acholeplasma sp. strain 0502-C1 and Acholeplasma sp. strain PS-1 were osmotically labile to Kappa buffer, even when it was used at $10 \times$ concentration. We washed the cells of these organisms four times with fresh Edward medium without horse serum or radioactive acetate; this was followed by a final wash with 10X Kappa buffer.

The washed cells were freeze-dried until the lipids were extracted as described previously (4). The lipids were purified (4) and weighed to $10^{-6} \mathrm{~g}$ by using an electromicrobalance (model ME30; Mettler Instrument Corp., Hightstown, N.J.).

\section{RESULTS}

The effects of different concentrations of serum in the medium on the incorporation of acetate radioactivity into the lipids of Mollicutes strains were tested by using $M$. gallisepticum and $A$. laidlawii B-PG9. For $M$. gallisepticum, the horse serum concentration in the medium was varied from 0.5 to $10.0 \%(\mathrm{vol} / \mathrm{vol})$; for $A$. laidlawii B-PG9 it was varied from 0 to $10 \%$ ( $\mathrm{vol} / \mathrm{vol})$. From M. gallisepticum grown in the presence of $0.5 \%$ serum, we recovered $8.51 \times 10^{3} \mathrm{dpm}$ of lipids per $\mathrm{mg}$, whereas in the presence of $10.0 \%$ serum we recovered $1.44 \times 10^{2} \mathrm{dpm}$ of lipids per mg. From A. laidlawii grown without serum, we recovered $1.55 \times 10^{8} \mathrm{dpm}$ of lipids per mg, whereas in the presence of $10 \%$ serum we recovered $4.86 \times 10^{7} \mathrm{dpm}$ of lipids per mg (Fig. 1). We concluded that although serum concentration inversely affected the incorporation of acetate radioactivity into the lipids of $A$. laidlawii B-PG9, over the same serum concentration range there was little effect on such incorporation into the lipids of $M$. gallisepticum. Furthermore, at any concentration of serum, there was about 500 times more radioactivity incorporated into A. laidlawii B-PG9 lipids than into the lipids of $M$. gallisepticum.

We tested the various Mollicutes strains to determine whether they could synthesize lipid from acetate (Table 1). We found that all Mycoplasma species, all $U$. urealyticum serovars, and Acholeplasma sp. strains L1, GF-1, J233, and PS-1 synthesized relatively little or no ${ }^{14} \mathrm{C}$-labeled lipid from $\left[{ }^{14} \mathrm{C}\right]$ acetate; six other Acholeplasma isolates produced significantly more ${ }^{14} \mathrm{C}$-labeled lipid from $\left[{ }^{14} \mathrm{C}\right]$ acetate.

\section{DISCUSSION}

We found that the Mycoplasma species which we tested, like all other species that have been examined, convert relatively little acetate to lipids $(4,6)$. Acholeplasma species have been shown to synthesize lipids from acetate $(4,6)$. However, this ability can no longer be used to differentiate Acholeplasma from Mycoplasma species, because we found that recently described A. florum and Acholeplasma sp. strains from coconut flowers and an insect synthesize very little lipid from acetate.

A. florum, A. morum 72-043, and Acholeplasma axanthum S743 exhibit positive growth responses to additions of fatty acids and albumin when they are grown in sterol-free growth media $(5,11,12 ;$ J. G. Tully, unpublished data). As stated above, we found that $A$. florum strains produce little lipid from acetate, and we have reported previously that $A$. morum S2 and $A$. axanthum $\mathrm{S} 743$ produce intermediate levels of acetate-derived lipids (4). All of these findings may be related, in that the inability or diminished capacity of the strains to convert acetate to lipids may reflect a need for, and hence a positive growth response to, longer-chain fatty acids or perhaps phospholipids or both. We consider phospholipid requirement a strong possibility, because in acholeplasmas phospholipids are the primary repository of acetate-derived radioactivity (4).

TABLE 1. Synthesis of ${ }^{14} \mathrm{C}$-labeled lipids from $\left[{ }^{14} \mathrm{C}\right]$ acetate by Mollicutes strains

\begin{tabular}{|c|c|c|}
\hline Strain & $\begin{array}{l}\text { Lipid synthesis } \\
\text { (kdpm of lipid } \\
\text { per } \mathrm{mg} \text { ) }\end{array}$ & $\begin{array}{l}\text { No. of } \\
\text { cell } \\
\text { batches } \\
\text { tested }\end{array}$ \\
\hline A. laidlawii B-PG9 & $341.00 \pm 25.11^{a}$ & 5 \\
\hline A. laidlawii $643 \mathrm{~N}$ & $130.49 \pm 1.26$ & 3 \\
\hline A. laidlawii $\mathbf{H} 3-10$ & $136.27 \pm 2.28$ & 2 \\
\hline A. morum $\mathrm{S} 2$ & $4.24 \pm 0.11$ & 3 \\
\hline A. hippikon $\mathrm{C} 1$ & $3.37 \pm 0.05$ & 3 \\
\hline A. florum L1 (lemon) & $0.36 \pm 0.95$ & 6 \\
\hline A. florum GF-1 (grapefruit) & $0.04 \pm 0.01$ & 3 \\
\hline $\begin{array}{l}\text { Acholeplasma sp. strain } \mathrm{J} 233 \\
\text { (coconut palm) }\end{array}$ & $0.28 \pm 0.03$ & 3 \\
\hline Acholeplasma sp. strain PS-1 (insect) & $0.04 \pm 0.01$ & 3 \\
\hline $\begin{array}{l}\text { Acholeplasma sp. strain 0502-CL1 } \\
\text { (broccoli) }\end{array}$ & $43.59 \pm 2.26$ & 3 \\
\hline M. gallisepticum S6 & $0.19 \pm 0.02$ & 5 \\
\hline M. bovigenitalium PG11 & $0.24 \pm 0.19$ & 3 \\
\hline M. pulmonis ATCC 19612 & $0.01 \pm<0.00$ & 2 \\
\hline$M$. hominis ATCC 14027 & $0.17 \pm 0.11$ & 3 \\
\hline M. arginini $\mathrm{G} 230$ & $0.05 \pm 0.01$ & 3 \\
\hline Mycoplasma sp. strain MQ3 (insect) & $0.03 \pm 0.02$ & 3 \\
\hline $\begin{array}{l}\text { Mycoplasma sp. strain pommier } \\
\text { (apple) }\end{array}$ & $0.19 \pm 0.07$ & 3 \\
\hline $\begin{array}{l}\text { Mycoplasma sp. strain melaleuca } \\
\text { (flower) }\end{array}$ & $0.02 \pm 0.01$ & 3 \\
\hline $\begin{array}{l}\text { Mycoplasma sp. strain } 831-\mathrm{C} 4 \\
\text { (lettuce) }\end{array}$ & $0.29 \pm 0.03$ & 3 \\
\hline$U$. urealyticum 1 (serovar 1$)$ & 0.01 & 1 \\
\hline U. urealyticum 27 (serovar 3 ) & 0.01 & 1 \\
\hline U. urealyticum 58 (serovar 4) & 0.01 & 1 \\
\hline U. urealyticum $354[\mathrm{NIH}]$ (serovar 5) & 0.01 & 1 \\
\hline U. urealyticum $\mathrm{Pi}$ (serovar 6) & $0.02 \pm<0.00$ & 2 \\
\hline U. urealyticum Co (serovar 7 ) & $<0.01$ & 1 \\
\hline U. urealyticum $\mathrm{T} 960(\mathrm{Cx})$ (serovar 8$)$ & $0.03 \pm<0.00$ & 3 \\
\hline U. urealyticum U38 (serovar 13 ) & 0.01 & 1 \\
\hline
\end{tabular}

${ }^{a}$ Mean \pm standard deviation. 
Although to us it is less likely, it is possible that high rates of fatty acid turnover result in apparently low incorporation. Preliminary studies only with $A$. axanthum $\mathrm{S} 743$ showed that this organism did not release significant amounts $(<1 \%)$ of ${ }^{14} \mathrm{CO}_{2}$ during the first $22 \mathrm{~h}$ of growth in Edward medium containing $\left[{ }^{14} \mathrm{C}\right]$ acetate (unpublished data). Also, other studies with different acholeplasma showed that the residual lipid-extracted pellets of whole cells grown in the presence of $\left[{ }^{14} \mathrm{C}\right]$ acetate were not radioactive (unpublished data).

All eight serovars of $U$. urealyticum converted very little if any acetate to lipid. This finding is in conflict with an earlier study of $U$. urealyticum P108 (10). Although isolate P108 was unavailable, we studied the same serovar (serovar 6) and found no conversion. All eight Ureaplasma serovars that we studied had been subcultured many times, and perhaps they had lost their ability to convert acetate to lipid. Romano has reported that $U$. urealyticum P108 has lost its ability to synthesize lipid from acetate and that some freshly isolated ureaplasmas lose this property after laboratory passage (N. Romano, unpublished data).

\section{LITERATURE CITED}

1. Beaman, K. D., and J. D. Pollack. 1981. Adenylate energy charge in Acholeplasma laidlawii. J. Bacteriol. 146:1055-1058.

2. Freeman, B. A., R. Sissenstein, T. T. McManus, J. E. Woodward, I. M. Lee, and J. B. Mudd. 1976. Lipid composition and lipid metabolism of Spiroplasma citri. J. Bacteriol. 125:946-954.

3. Freundt, E. A. 1983. Principles of mycoplasma classification and taxonomy, p. 9-13. In S. Razin and J. G. Tully (ed.), Methods in mycoplasmology, vol. 1. Mycoplasma characterization. Academic Press, Inc., New York.

4. Herring, P. K., and J. D. Pollack. 1974. Utilization of [1${ }^{14} \mathrm{C}$ ]acetate in the synthesis of lipids by acholeplasmas. Int. J. Syst. Bacteriol. 24:73-78.

5. McCoy, R. E., H. G. Basham, J. G. Tully, D. L. Rose, P. Carle, and J. M. Bové. 1983. Acholeplasma florum, a new species isolated from plants. Int. J. Syst. Bacteriol. 34:11-15.

6. Pollack, J. D. 1978. Differentiation of Mycoplasma and Acholeplasma. Int. J. Syst. Bacteriol. 28:425-426.

7. Pollack, J. D. 1983. Localization of enzymes in mycoplasmas: preparatory steps, p. 327-336. In S. Razin and J. G. Tully (ed.), Methods in mycoplasmology, vol. 1. Mycoplasma characterization. Academic Press, Inc., New York.

8. Robertson, J. 1978. Bromthymol blue broth: improved medium for detection of Ureaplasma urealyticum (T-strain mycoplasma). J. Clin. Microbiol. 7:127-132.

9. Robertson, J. A., and G. W. Stemke. 1982. Expanded serotyping scheme for Ureaplasma urealyticum strains isolated from humans. J. Clin. Microbiol. 15:873-878.

10. Romano, N., S. Rottem, and S. Razin. 1976. Biosynthesis of saturated and unsaturated fatty acids by a T-strain mycoplasma (Ureaplasma). J. Bacteriol. 128:170-173.

11. Rose, D. L., J. G. Tully, and R. A. Del Guidice. 1980. Acholeplasma morum, a new non-sterol-requiring species. Int. J. Syst. Bacteriol. 30:647-654.

12. Tully, J. G., and S. Razin. 1970. Acholeplasma axanthum sp. n.: a new sterol-nonrequiring member of the Mycoplasmatales. J. Bacteriol. 103:751-754. 